\title{
De ingetrokken 403-verklaring van Shell: een tactische zet?
}

\author{
Mr. E.A. van Dooren*
}

\begin{abstract}
De afgelopen tijd berichtten de media uitgebreid over het feit dat Shell haar 403-verklaring ten aanzien van groepsmaatschappij NAM had ingetrokken. In deze column onderzoekt de auteur de (mogelijke) motieven van Shell om deze verklaring in te trekken, en wat dit betekent voor de positie van Shell met betrekking tot de aardbevingsschade in Groningen.
\end{abstract}

\section{Inleiding}

Als iemand mij de afgelopen jaren had verteld dat de 403-verklaring ooit een onderwerp zou zijn tijdens een late-night praatprogramma, dan had ik deze persoon zeer waarschijnlijk niet geloofd. ${ }^{1}$ De afgelopen tijd was er echter geen ontkomen aan. De media berichtten uitgebreid over het feit dat Shell haar 403-verklaring ten aanzien van groepsmaatschappij NAM had ingetrokken. Het begon met dagblad Trouw, dat op zaterdag 27 januari 2018 schreef dat Shell met deze intrekking ongemerkt de NAM op afstand had geplaatst en dat Shell hierdoor niet langer aansprakelijk is voor schikkingen die de NAM treft om de aardbevingsschade in Groningen te vergoeden. ${ }^{2}$ Dit bericht werd al snel door andere media opgepikt. ${ }^{3}$ In het bijzonder Het Financieele Dagblad berichtte uitvoerig over deze kwestie. ${ }^{4}$ De algemene tendens in de berichtgeving in de media was dat Shell (in ieder geval de schijn heeft gewekt dat zij) bewust onder haar aansprakelijkheid voor schulden

* Mr. E.A. van Dooren is promovendus en docent bij het Molengraaff Instituut voor Privaatrecht (Universiteit Utrecht).

De auteur schrijft een proefschrift over de 403-verklaring.

1. Op dinsdag 30 januari 2018 sprak Marjan van Loon (president-directeur Shell Nederland) in het praatprogramma Jinek over de commotie die was ontstaan na de berichtgeving dat Shell haar 403-verklaring ten aanzien van de NAM had ingetrokken.

2. J. Kleinnijenhuis, Shell zet de Nam op afstand. Wie draait er straks op voor de schade in Groningen?, Trouw 27 januari 2018.

3. Onder meer: 'Shell niet langer aansprakelijk voor schulden NAM', Dagblad van het Noorden 27 januari 2018, dvhn.nl, 'Oproep tot boycot Shell op sociale media', Dagblad van het Noorden 27 januari 2018, dvhn.nl, 'Oppositie: opheldering over aansprakelijkheid Shell', BNR Nieuwsradio 27 januari 2018, bnr.nl en S. Sjouwerman, Is Shell nu wel of niet aansprakelijk voor schade die de NAM veroorzaakt?, NOS 27 januari 2018, nos. $\mathrm{nl}$.

4. 'Shell niet meer aansprakelijk voor schulden NAM', Het Financieele Dagblad 27 januari 2018, fd.nl, C. Grol, Een garantstelling wordt níet ingetrokken omdat het zo goed gaat, Het Financieele Dagblad 29 januari 2018, 'Shell is zeker geen "force for good"', Het Financieele Dagblad 30 januari 2018, 'Even $€ 6$ mrd aftikken', Het Financieele Dagblad 1 februari 2018, B. van Dijk \& P. Couwenbergh, Optreden Shell bij NAM 'pikant', Het Financieele Dagblad 1 februari 2018, fd.nl en P. Couwenbergh, De ‘403’, Het Financieele Dagblad 2 februari 2018. van de NAM in verband met aardbevingsschade in Groningen probeert uit te komen.

\section{De 403-verklaring}

De deponering van een 403-verklaring is een van de voorwaarden van het groepsregime ex artikel 2:403 van het Burgerlijk Wetboek (BW). ${ }^{5}$ Het groepsregime biedt een groepsmaatschappij (“403-maatschappij', in casu de NAM) onder meer de mogelijkheid om vrijgesteld te worden van de verplichting om jaarlijks een jaarrekening openbaar te maken. Hierdoor hebben haar crediteuren geen inzicht in de financiële positie van hun debiteur. Ter compensatie van dit gebrek aan inzicht dient de moedermaatschappij (in casu Shell) ingevolge artikel 2:403 lid 1 sub f BW een verklaring te deponeren op grond waarvan zij zich hoofdelijk aansprakelijk stelt voor de schulden die voortvloeien uit rechtshandelingen van de 403-maatschappij. Crediteuren van de 403-maatschappij krijgen op grond van deze verklaring tevens een vordering op de moedermaatschappij, waarvan de financiële positie wél inzichtelijk is. ${ }^{6}$

De moedermaatschappij is op grond van een 403-verklaring niet aansprakelijk voor schulden van de 403-maatschappij die uit de wet voortvloeien. Volgens de minister hoeven crediteuren wier vordering uit de wet voortvloeit, niet te worden gecompenseerd voor een gebrek aan inzicht in de financiële positie van de 403-maatschappij. Het ontstaan of de omvang van een vordering die uit de wet voortvloeit, is namelijk niet gebaseerd op een afweging van de (latere) crediteur ten aanzien van de financiële positie van de desbetreffende rechtspersoon. ${ }^{7}$

\section{Aardbevingsschade}

De verplichting van de NAM tot het vergoeden van aardbevingsschade aan gedupeerde Groningers betreft een verplichting tot schadevergoeding op grond van onrechtmatige daad. Dergelijke schulden vloeien niet voort uit een rechtshandeling van de NAM, maar uit de wet. Shell zou op grond van de 403verklaring nooit aansprakelijk zijn voor deze schulden van de NAM. Ook minister Wiebes van Economische Zaken en Kli-

\footnotetext{
5. Daarnaast moeten - onder meer - de financiële gegevens van de 403maatschappij zijn verwerkt in de geconsolideerde jaarrekening van de moedermaatschappij en moeten de aandeelhouders of leden van de 403maatschappij jaarlijks instemmen met afwijking van de jaarrekeningvoorschriften.

6. Kamerstukken II 1969/70, 10689, 3, p. 14.

7. Kamerstukken II 1969/70, 10689, 3, p. 14, en 4, p. 30.
} 


\section{Maandblad}

Ondernemingsrecht

maat onderstreepte recentelijk dat de verplichting tot het vergoeden van aardbevingsschade ten opzichte van de gedupeerden in Groningen een wettelijke verplichting van de NAM is die niet onder de 403-verklaring van Shell zou vallen. ${ }^{8}$

De moeilijkheid in deze casus zit hem in het recent opgestelde schadeprotocol voor de afhandeling van de aardbevingsschade. ${ }^{9}$ Op 31 januari 2018 meldde minister Wiebes aan de Tweede Kamer dat de schade voor de gedupeerden in Groningen voortaan door de overheid wordt afgehandeld. De NAM is daar inhoudelijk niet bij betrokken, maar dient wel zorg te dragen voor de financiering. Hiertoe hebben de Staat der Nederlanden en de NAM een overeenkomst gesloten. Het sluiten van deze overeenkomst is wél een rechtshandeling van de NAM. Indien Shell haar 403-verklaring niet had ingetrokken vóór het sluiten van deze overeenkomst, zou zij op grond van deze verklaring hoofdelijk aansprakelijk zijn voor de schulden van de NAM in verband met de financiering van de afhandeling van de aardbevingsschade.

\section{De reden voor de intrekking van de 403- verklaring volgens Shell}

Shell heeft verklaard dat de NAM op grond van Europese regelgeving ${ }^{10}$ vanaf het boekjaar 2016 verplicht is haar betalingen aan overheden openbaar te maken. De NAM heeft besloten om niet slechts deze betalingen aan overheden bekend te maken, maar om een volledige jaarrekening openbaar te maken. Deze jaarrekening is in het voorjaar van 2017 gedeponeerd bij het handelsregister. Aangezien de NAM geen gebruik meer makt van de jaarrekeningvrijstelling van het groepsregime bestaat er volgens Shell geen reden om de 403verklaring - als voorwaarde van het groepsregime - verder van kracht te laten zijn. Daarom heeft Shell op 8 juni 2017 haar 403-verklaring ingetrokken door een zogenoemde intrekkingsverklaring ex artikel 2:404 lid $1 \mathrm{BW}$ te deponeren.

\section{Analyse}

Ik volg de redenering van Shell dat het niet nodig is om haar 403-verklaring verder van kracht te laten zijn als de NAM geen gebruik meer maakt van de jaarrekeningvrijstelling van het groepsregime. Toch vraag ik mij af wat in deze situatie de oorzaak is en wat het gevolg. Heeft Shell haar 403-verklaring ingetrokken omdat de NAM een jaarrekening openbaar heeft gemaakt, of heeft de NAM een jaarrekening openbaar gemaakt omdat Shell haar 403-verklaring wilde intrekken? Een cynicus zal het laatste denken.

Het schadeprotocol met betrekking tot de afhandeling van de aardbevingsschade zal niet van de ene op de andere dag zijn opgesteld. Hoewel het speculeren blijft, is het niet ondenkbaar

8. Kamerstukken II $2017 / 18,33529,422$, p. 2.

9. Kamerstukken II 2017/18, 33529, 423.

10. Art. 42 lid 1 Richtlijn jaarrekeningen 2013/34/EU, PbEU 2013, L 182/19. Zie ook art. 3 lid 1 Besluit rapportage van betaling aan overheden en art. 1 Transparantierichtlijn 2013/50/EU, PbEU 2013, L 294/13, waar art. 6 Richtlijn 2004/109/EG, PbEU 2014, L 390/38 wordt gewijzigd. dat Shell haar 403-verklaring heeft ingetrokken in anticipatie op de vaststelling van het schadeprotocol en de financieringsovereenkomst tussen de NAM en de overheid. Shell heeft weliswaar toegezegd dat zij haar verantwoordelijkheid zal nemen ten aanzien van de ontstane (en toekomstige) aardbevingsschade en hiervoor een schriftelijke verklaring wil afgeven, ${ }^{11}$ maar zij heeft daarbij natuurlijk wel een sterkere onderhandelingspositie dan wanneer zij direct op grond van de 403-verklaring aansprakelijk zou zijn.

Of bovenstaande cynische blik terecht is, zal binnenkort blijken. Veel hangt af van de precieze bewoordingen van de verklaring van Shell. Sluit deze aan bij de tekst van een 403-verklaring en stelt Shell zich zonder beperkingen hoofdelijk aansprakelijk voor de schulden die uit de financieringsovereenkomst tussen de NAM en de overheid voortvloeien? Of worden er in de verklaring voorwaarden, maxima en/of beperkingen ten aanzien van de aansprakelijkheid van Shell opgenomen? Een discussiepunt kan bijvoorbeeld de vergoeding van immateriële schade van gedupeerden zijn. Op 1 maart 2017 heeft de Rechtbank Noord-Nederland geoordeeld dat de NAM verplicht is aan een deel van de inwoners van het Groningenveld immateriële schade te vergoeden. ${ }^{12}$ De NAM is tegen dit oordeel in hoger beroep gegaan. Het is de vraag of de verklaring van Shell ook zal zien op deze immateriële schade.

11. 'Shell Nederland staat achter NAM en Groningen', Shell 30 januari 2018, shell.nl, 'Shell ook op papier garant voor alle schade die de NAM moet betalen', NOS 1 februari 2018, nos.nl, L. Hoeks, Shell bezweert Kamer: wij staan garant voor NAM, Het Financieele Dagblad 2 februari 2018 en Marjan van Loon (president-directeur Shell Nederland) bij het rondetafelgesprek van de vaste commissie van Economische Zaken en Klimaat van de Tweede Kamer op 1 februari 2018 omtrent de betaalcapaciteit van de NAM.

12. Rb. Noord-Nederland 1 maart 2017, ECLI:NL:RBNNE:2017:715. 